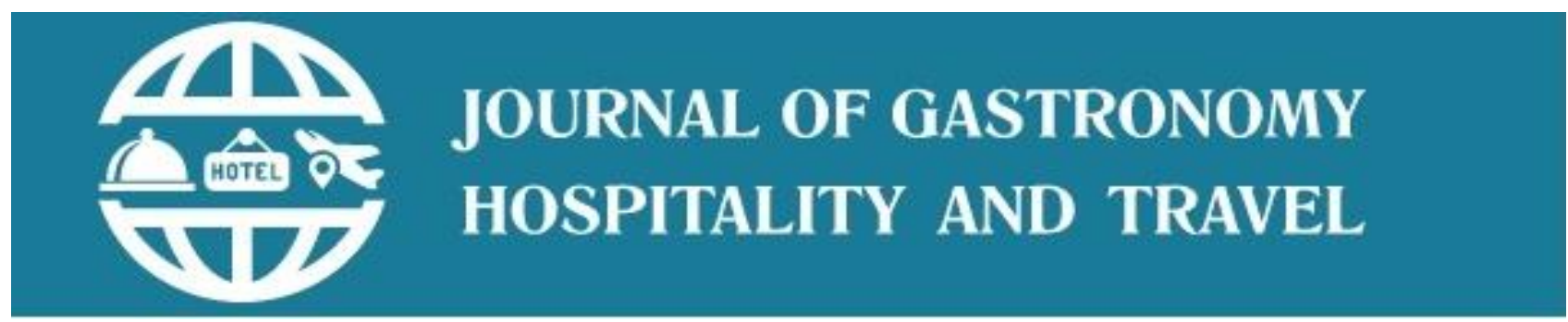

ISSN: $2619-9548$

Journal homepage: www.joghat.org, http://dergipark.gov.tr/joghat

Journal of Gastronomy, Hospitality and Travel (JOGHAT)

2018 - Volume: 1 Issue: 1

Page: $18-28$

Received: 29.12 .2017

Revised: 02.01 .2018

Accepted: 11.01 .2018

\title{
Research Article \\ INVESTIGATION OF THE NEEDS OF HIGHER EDUCATION TOURISM STUDENTS FOR ENGLISH
}

\author{
Davut Uysal $^{1 *}$ (orcid.org/0000-0003-4451-169X) \\ Saadet Pınar Temizkan ${ }^{2}$ (orcid.org/0000-0002-8200-9564) \\ Nazmi Taslacı ${ }^{1}$ (orcid.org/0000-0002-1540-8784) \\ ${ }^{1}$ Tourism Management, Institute of Social Sciences, Eskişehir Osmangazi University, Eskişehir, Turkey. \\ ${ }^{2}$ Gastronomy and Culinary Arts Programme, Faculty of Tourism, Eskişehir Osmangazi University, Eskişehir, Turkey. \\ ${ }^{1}$ Tourism Management, Institute of Social Sciences, Eskişehir Osmangazi University, Eskişehir, Turkey.
}

\begin{abstract}
This research intended to carry out a needs analysis for English language at higher education tourism students in Turkey. Therefore, a questionnaire was developed, and then its validity was confirmed. The participants of this research were 393 tourism students from 26 universities in Turkey. The data gathered through the developed questionnaire were submitted for a descriptive analysis. The results revealed the following findings; a- the English language education presented at tourism related departments is not satisfactory, b- the English text books chosen in line with the principles of general English language education do not satisfy the tourism students' needs c- tourism students are not adequately trained about their language needs regarding their future career d- English language classes should be re-evaluated and redesigned with regards to content and teaching methods for more fruitful learning, elistening and speaking skills in English courses should be given more importance, f- course contents should be re-designed under the principles of English for Specific Purposes. It is hoped that the findings of this study will contribute to new EFL curriculum designs, text book developments to facilitate English teaching and learning at Tourism departments at higher education institutions in Turkey.
\end{abstract}

Keywords: Needs analysis, Tourism students, ESP

To cite this document: Uysal, D., Temizkan, S. P. ve Taslac1, N. (2018). Investigation of The Needs of Higher Education Tourism Students for English, Journal of Gastronomy Hospitality and Travel, 1(1), 18-28. DOI: 10.33083/joghat.2018.2

* Corresponding Author: davutuysal@gmail.com 


\section{INTRODUCTION}

The importance of international tourism has been increasing by time. As a consequence of that, the tourism sector has been growing, and the need for qualified human power to employ in the sector has also been increasing accordingly. Tourism sector is known to be the one which most intensely delivers its services with the use of human power differently from most other sectors. Therefore, it is becoming more important to train human power to be employed in tourism sector because the profitability and sustainability of tourism are closely dependent on the qualifications of the human power employed in the tourism sector (Vellas and Becherel, 1995).

To meet the needs of qualified employees in tourism sector, the number of tourism-related programs at higher education institutions has been increasing rapidly in the world in recent years. The same is true for Turkey as well. Teaching a foreign language in these tourism programmes is the most basic aim for the programme designers at these high education institutions. The importance of having a good foreign language can be understood better with the following example. As suggested by Demirkol and Pelit (2002), having good English has become more important than having a diploma in the field of tourism. In spite of the high need for such qualified employees with a good foreign language, research reveals that most common employee-related problems in Turkish tourism is employees' lack of necessary skills in a foreign language. Foreign language teaching is considered to be equal to the teaching of English without considering the differences in students' language proficiency levels in Turkey because it is the most popular foreign language in the world (Kinsiz, 2005).

\subsection{Aim of the Study}

The aim of this research is presenting the results of needs analysis carried out on higher education tourism students in Turkey. The aim of the needs analysis carried out with both instructors and learners is to come up with some suggestions regarding the underlying problems of foreign language learning of the students at tourism faculties. To be able to make a good justification for the findings of the needs analysis, relevant research in the field were investigated and solutions to the problems mentioned above are offered with this study. Therefore, the major goals of this study can be summed up as follows;

- Finding out the deficits of English courses given to students at tourism faculties

- Analysing how students perceive the English courses they take at their departments

- Considering the outcomes of the needs analysis, the curriculum for tourism English is compared to the characteristics of English for Specific Purposes (Nunan, 1998)

- Contributing to the literature and curriculum regarding how to teach English for tourism students

To be able to suggest relevant solutions to the goals stated above, the following research questions were addressed in this research;

- What is the general attitude of tourism students towards English in Turkey?

- Do they find English easy or difficult to learn?

- What language background do students come from?

- Are students willing to learn English?

- Which teaching methods do students find the most beneficial?

- Which teaching methods do students find the least beneficial?

- What work areas are they willing for in their future career?

- What level of English do they think they are?

- What language areas do they find most important when they consider a career in tourism?

- What language areas do they find least important when they consider a career in tourism?

- What type of English teaching is used in the classrooms by the instructors?

- What are the gaps between the current teaching techniques and the principles of English for Specific Purposes?

\subsection{Scope of the study}


This study was carried out within the scope of all higher education institutions offering tourism education in Turkey. The questionnaire which includes 47 items regarding English language teaching delivered to higher education tourism students and responses were taken from 26 universities. 393 questionnaires were returned to the researchers by the participants.

\subsection{Significance of the study}

Foreign language instructions at tourism faculties have been a big problem for English lecturers as mentioned by most language teachers teaching tourism faculties. Students at tourism faculties cannot have a good command of English when they finish their departments. The findings of this study are very significant because it intends to find out the needs of tourism students for foreign language. The outcomes of this needs analysis is expected to lead to the redesigning of the language programs at the faculties to improve English teaching as a foreign language. This study will also offer significant contributions to the literature of needs analysis regarding foreign language learning of tourism students at higher education because the number of studies conducted to reveal the needs of tourism students at universities is very few.

\section{REVIEW OF LITERATURE}

There are a lot of researchers in the literature suggesting that, as the contexts where a foreign language is taught vary, there is also a need for designing language teaching methods and contents to satisfy the learners' needs (Gatehouse, 2001; Hutchinson and Waters, 1987). The English courses offered to students at tourism departments are mainly concerned with the teaching of general English. In other words, the content of English language teaching is not designed considering that the students will be employed in the tourism business when they finish their schools. With this regard, receiving feedback from tourism students regarding what they think they need, what they want in the planning of English instruction is very important. It is also important to know if they believe a career in the tourism business, what content areas need to be added into or deleted from the current teaching planning so that they can find better jobs in the future. There is also a need to find out want methods to be used in English language teaching in tourism departments and how the currently used methods need to be modified to fit their future careers.

Designing an English curriculum that adequately meets tourism students' needs; the needs of educational institutions where students are taught should also be considered and modified depending on the feedback received from students and lecturers teaching English. To be able to offer students an atmosphere where they can sufficiently be educated in parallel with the needs in their future career; learners' needs and employers' needs should be made clear and the needs of curriculum designers and teachers should also be met. In this study, employers' needs will be disregarded as they are out of the researchers' concern for now.

The term of "needs" has been studied in much research, and many definitions have been suggested regarding "needs". Brindley (1989) defined "needs" as objective and subjective needs, and Berwick (1989) suggested another definition regarding "needs" and defined it as perceived and felt "needs". Brindley (1989) also claimed another definition for "needs" and suggested as the needs based on targets and learning needs of students, product and process. Hutchinson and Waters (1987) defined "needs" as what is necessary, what students want and lack.

West (1994) suggests that the analysis of needs was usually done informally till the 1970s. Therefore, the amount of research conducted on this issue was very limited. Because of this, language instructors conducted their own needs analysis using some informal analysis methods regarding their learners' needs for foreign language. Richterich and Chancerell (1980) suggest some major aims for such needs analysis; which are mainly about the identification of some elements which help find out what is important and necessary for learners.

Brindley (1989) also suggest that when needs are found out, these needs are named as objective and perceived needs. If learners learn English to fulfil the requirements to be able to get a degree, they feel a strong 
need to study English as it is perceived as their main objective. On the other hand, when the needs at a certain setting are derived by insiders, these needs are felt by the learners. The needs based on the product are similar to those of the needs based on situation or goal whereas the needs based on the process are closely related to the situations where learning takes place. Dudley-and St John (1998) claim that the needs based on objective, perception and product are associated with the analysis of the target situation, and the needs which are subjective, felt and based on the process are associated with the analysis of the situation where learning takes place. They also suggest the analysis of the present situation in detail. This analysis aims at finding out what learners already know; thus it also helps to reveal what learners do not have but need. Hutchinson and Waters (1987) claim a different definition for "needs" and classify "needs" as what is necessary, what learners want and what they lack. The needs of "necessities" are determined considering the aims of the target learners. Thus, it could be possible to see if there is a mismatch between the needs perceived by course designers and teachers.

\subsection{English for Tourism}

The importance of having a good level of English for those who are likely to be employed in the tourism sector has been increasing in the rapidly globalizing world. Afrazi and Rezapoorian (2014) claim that the students engaged in the tourism-related jobs lack the skills of efficiently performing their language skills as they are engaged in communications with customers. Therefore, for those who learn English for a future career in the tourism sector, it is very important to design opportunities for the successful fulfilment of some tasks considering the aim of the course and the knowledge that learners feel the need to be fully prepared for their future tourism career.

\subsection{General English vs English for Tourism}

It is obvious that there are a lot of differences between teaching English as a foreign language and Teaching English for Tourism purpose. In EFL classrooms, teachers are expected to stick to a specific lesson plan covering all four skills, which are speaking, writing, reading and listening. However, in the courses aiming to teach English to tourism students, the aim is to deal with language in context without putting much focus on grammar rules or how to structure the language in speaking production (Xhaferi, 2010). In other words, the skills taught within the classroom environment are the ones that learners feel the need for. The main focus of the classes are on communication-related skills, and therefore, the main purpose is always improving students' speaking skills to make them competent speakers in their future careers when they need to use their language.

Another significant difference between general English and English for tourism is that EFL classes aim to teach English beginning from the earliest stages and covering all essential parts, but it is not the same in teaching English for Tourism, which teaches through intensive courses to prepare students for their work environments considering their vocational needs (Xhaferi, 2010). Another point to be considered when to talk about the differences between General English and English for tourism is that English for tourism contains specialist language and content as suggested by Robinson (1991). For example, English for tourism classes have to offer students dialogues with "future" customers, or they may be given an opportunity to learn about hotels as their future workplaces.

The last difference between the general English teaching and teaching English for tourism is that English for tourism classes are more "learner-centred" (Hutchinson and Waters, 1987). In this approach, learners learn about a restricted area rather than learning about each skill as done in general English teaching. As suggested by Hutchinson and Waters (1987), feedbacks are gathered for learners to find out which restricted areas to teach. In such classroom settings, learners do not have to put equal emphasis on all parts.

\subsection{Relevant Studies in the Field}

In a study, Keyoonwong (1998) studied on the needs of learners of English in the tourism industry in Chiang Mai. It was found in the study that tourism staff gives more importance to the skills of speaking and listening, and they consider them as essential skills in tourism. Then reading, writing and translation come. In another study, Boonyawattana (1999) investigated the needs of tourism students regarding English. It was also 
found that speaking was the most important skill and then listening, reading and writing came. Another study was carried out by Ekici (2003) to find out the needs of tour guide students for English at Başkent University. The participants of the research were English language instructors, curriculum coordinators and students. The results revealed that the vocabulary that they commonly use in their career as they speak and listen should be more emphasized to satisfy the needs of tour guide students.

\section{METHOD}

\subsection{Participants}

The participants in this study were 393 Higher education students from tourism-related departments from 26 universities in Turkey. The participants volunteered to participate in the study, and they voluntarily replied the online questionnaire which aims to reveal their needs for English.

\subsection{Instrument for Data Collection}

The data collected in this study were gathered by using a developed needs analysis questionnaire. The use of a questionnaire is a widely used method for data collection in most research. A questionnaire in the Turkish language was used to find answers. The questionnaire consisted of 47 items in total. The items were about measuring students' abilities in English, learners' specific and general needs for English and the topics which students find more attention-taking to include in their courses. The items between 1 and 9 aimed to gather data regarding demographic information of the participants, the items between 10 and 16 aimed to gather information about students' levels of English upon their declaration, the items 17 and 18 were about the language teaching activities that students want to be used in their English courses and which they want to be used in their future English courses for better language learning. The items of 19, 20 and 21 were about their preferences for learning English. The items between 22 and 47 are all about specific skills in English, general skills needed by tourism students.

\subsection{Questionnaire Construction}

The steps taken to construct the questionnaire are summed up as follows. First, the questionnaire was constructed following a detailed literature review in the relevant field, and the questionnaire was piloted on 20 tourism students which are considered to have similar characteristics with the participants of the study. Students were also requested to give their feedbacks through some open-ended questions in the questionnaire to improve the coverage of the developed questionnaire. 5 interviews were also conducted with the students to be able to more effectively elicit the required information. Then based on the points mentioned above, the items in the developed questionnaire were revised and reconstructed, and then a survey was conducted with some field experts from Eskişehir Osmangazi University, Tourism Faculty to gather feedback regarding the general state of the draft questionnaire and modify the items. Thus the face and content validity of the questionnaire was also tested and confirmed. Third, to be sure that the items in the questionnaire were unambiguous for the participants, another study with 3 lecturers among the selected teaching staff from the Hospitality Department at Eskişehir Osmangazi University was conducted for the piloting purpose. As a result of the collected feedback, some modifications were made on the items in the questionnaire, and some of the items were removed from the questionnaire, and some new ones were also included in it. Fourth, the reliability of the questionnaire was constructed through Cronbach's alpha, and $\alpha$ was found to be 82 .

\subsection{Procedure}

A digital version of the developed questionnaire was constructed and the link to the questionnaire was shared on the closed social media groups of tourism students upon the permission of the group responsible. When access to target students was possible, the printed version of the questionnaire was used by the researchers. Some of the participants were sent the link to the questionnaire through their e-mails. It took 2 months to collect the data through the questionnaire.

\section{DATA ANALYSIS}

The data gathered with the questionnaire were analysed by submitting for the SPSS 20 . This study used a descriptive research design. The mean scores of each participant were calculated and computerised. The data 
then was submitted for Cronbach Alpha analysis for the reliability of the questionnaire. The frequency analysis and One Way ANOVA Tukey test were conducted for multiple comparisons of the classes.

\section{RESULTS}

As seen in Table 1, the number of participants is 393 , and they were found to be from 26 universities in Turkey.

Table 1. Distribution of the Participants Depending on their Universities

\begin{tabular}{|c|c|c|c|c|c|}
\hline & & Frequency & Percent & $\begin{array}{l}\text { Valid } \\
\text { Percent }\end{array}$ & $\begin{array}{l}\text { Cumulative } \\
\text { Percent }\end{array}$ \\
\hline \multirow{27}{*}{ Valid } & Esogü & 63 & 16,0 & 16,2 & 16,2 \\
\hline & Selçuk University & 33 & 8,4 & 8,5 & 24,6 \\
\hline & Mustafa Kemal University & 13 & 3,3 & 3,3 & 27,9 \\
\hline & Çanakkale On. Mart. Uni. & 26 & 6,6 & 6,7 & 34,6 \\
\hline & Afyon Kocatepe Univ. & 24 & 6,1 & 6,2 & 40,8 \\
\hline & Necmettin Erb. Univ. & 17 & 4,3 & 4,4 & 45,1 \\
\hline & Balıkesir Univ. & 18 & 4,6 & 4,6 & 49,7 \\
\hline & Mersin Univ. & 20 & 5,1 & 5,1 & 54,9 \\
\hline & Adnan Menderes Univ. & 14 & 3,6 & 3,6 & 58,5 \\
\hline & Kastamonu Univ & 2 & ,5 &, 5 & 59,0 \\
\hline & İskenderun Teknik Univ. & 18 & 4,6 & 4,6 & 63,6 \\
\hline & Erciyes Univ. & 9 & 2,3 & 2,3 & 65,9 \\
\hline & Muğla Sıtkı Koçman Univ. & 16 & 4,1 & 4,1 & 70,0 \\
\hline & Nevşehir Hacı Bek. Vel. Uni. & 4 & 1,0 & 1,0 & 71,0 \\
\hline & Akdeniz Univ. & 11 & 2,8 & 2,8 & 73,8 \\
\hline & Anadolu Univ. & 26 & 6,6 & 6,7 & 80,5 \\
\hline & Trakya Univ. & 6 & 1,5 & 1,5 & 82,1 \\
\hline & Gazi Univ. & 4 & 1,0 & 1,0 & 83,1 \\
\hline & Kirklareli Univ. & 15 & 3,8 & 3,8 & 86,9 \\
\hline & İstanbul Aydın Univ. & 8 & 2,0 & 2,1 & 89,0 \\
\hline & Sinop Univ. & 14 & 3,6 & 3,6 & 92,6 \\
\hline & İstanbul Univ. & 4 & 1,0 & 1,0 & 93,6 \\
\hline & Dokuz Eylül Univ. & 6 & 1,5 & 1,5 & 95,1 \\
\hline & Yaşar Univ. & 5 & 1,3 & 1,3 & 96,4 \\
\hline & Sakarya Univ. & 2 & ,5 & ,5 & 96,9 \\
\hline & Atatürk Üniv. & 12 & 3,1 & 3,1 & 100,0 \\
\hline & Total & 390 & 99,2 & 100,0 & \\
\hline Missing & System & 3 & 8 & & \\
\hline Total & & 393 & 100,0 & & \\
\hline
\end{tabular}

When we examine the participants in terms of their department, Tourism and Hotel Management was found to have the highest percentage by $69 \%$ as seen in Table 2 . Then Travel Operation and Tour Guide come by $19.3 \%$. Gastronomy and Culinary Arts ranks the third by $\% 10.45$.

Table 2. Distribution of Departments of the Participants

\begin{tabular}{|c|c|c|c|c|c|}
\hline & & Frequency & Percent & Valid Percent & $\begin{array}{l}\text { Cumulative } \\
\text { Percent }\end{array}$ \\
\hline \multirow{5}{*}{ Valid } & $\begin{array}{l}\text { Tourism and Hotel } \\
\text { Management }\end{array}$ & 271 & 69,0 & 69,5 & 69,5 \\
\hline & $\begin{array}{l}\text { Travel Operation and Tour } \\
\text { Guide }\end{array}$ & 76 & 19,3 & 19,5 & 89,0 \\
\hline & $\begin{array}{l}\text { Gastronomy and Culinary } \\
\text { Arts }\end{array}$ & 41 & 10,4 & 10,5 & 99,5 \\
\hline & Other & 2 &, 5 &, 5 & 100,0 \\
\hline & Total & 390 & 99,2 & 100,0 & \\
\hline
\end{tabular}




\begin{tabular}{llll} 
Missing & System & 3 &, 8 \\
\hline Total & 393 & 100,0 \\
\hline
\end{tabular}

When we examine the participants depending on their classes, last year students came the first by $44.3 \%$, then the second year students came by $28.8 \%$. The third is the third year students by $21.9 \%$ and the last is the first year students by $4.3 \%$ as seen in Table 3 .

Table 3. Distribution of the Participants Depending on their Classes

\begin{tabular}{llllll}
\hline & & Frequency & Percent & Valid Percent & $\begin{array}{l}\text { Cumulative } \\
\text { Percent }\end{array}$ \\
\hline \multirow{4}{*}{ Valid } & 1. Class & 17 & 4,3 & 4,4 & 4,4 \\
\cline { 2 - 6 } & 2. Class & 113 & 28,8 & 29,0 & 33,3 \\
\cline { 2 - 6 } & 3. Class & 86 & 21,9 & 22,1 & 55,4 \\
\cline { 2 - 6 } & 4. Class & 174 & 44,3 & 44,6 & 100,0 \\
\cline { 2 - 6 } & Total & 390 & 99,2 & 100,0 & \\
\hline Missing & System & 3 &, 8 & & \\
\hline Total & & 393 & 100,0 & & \\
\hline
\end{tabular}

It was found in the study that $71.2 \%$ of the participants stated that they had experience in tourism in the past whereas $28 \%$ of them stated that they had no experience in tourism before.

$23.9 \%$ of them stated that they had English education at any preschool before whereas 75.3 of them stated that they had no prep-school education in English before in their educational background. $78.4 \%$ of the participants stated that they had prep-education on English at University whereas $20.9 \%$ of them stated that they did not have any preparatory class in English at their university.

When they were asked if they would work in tourism sector following their graduation, it was found that $41.7 \%$ of them stated that they wanted to work out of tourism sector after their graduation, and $35.6 \%$ of them stated that they would like to work in tourism sector whereas $21.9 \%$ of them stated that they did not think about it yet.

When the participants were asked which language skills they thought were the most beneficial for their career in tourism, it was found that 67.2 of them stated that speaking skill was the most beneficial for their future career in tourism. Then grammar came the second by 16.4 as seen in Table 4 .

Table 4. Which of the following do you think is the most beneficial for your career development in tourism?

\begin{tabular}{llllll}
\hline & & Frequency & Percent & Valid Percent & $\begin{array}{l}\text { Cumulative } \\
\text { Percent }\end{array}$ \\
\hline \multirow{5}{*}{ Valid } & Grammar & 64 & 16,3 & 16,4 & 16,4 \\
\cline { 2 - 6 } & Vocabulary & 24 & 6,1 & 6,2 & 22,6 \\
\cline { 2 - 6 } & Pronunciation & 13 & 3,3 & 3,3 & 25,9 \\
\cline { 2 - 6 } & Speaking & 264 & 67,2 & 67,7 & 93,6 \\
\cline { 2 - 6 } & Listening & 14 & 3,6 & 3,6 & 97,2 \\
\cline { 2 - 6 } & Reading & 9 & 2,3 & 2,3 & 99,5 \\
\cline { 2 - 6 } & Writing & 2 &, 5 &, 5 & \\
\cline { 2 - 6 } & Total & 390 & 99,2 & 100,0 & \\
\hline Missing & System & 3 &, 8 & & \\
\hline Total & & 393 & 100,0 & & \\
\hline
\end{tabular}

The findings regarding the English proficiency levels of the participants are as follows; for grammar, $43.8 \%$ of the participants were found to have claimed average grammar proficiency, then the percentage of those claiming that their grammar proficiency level was weak was $23.9 \%$. The percentage of those claiming very weak grammar proficiency was found to be $7.1 \%$. Only $4.1 \%$ of the participants stated that they had very good grammar proficiency. The percentage of those claiming good grammar proficiency was found to be $20.4 \%$. 
For vocabulary, the percentage of those claiming very good vocabulary proficiency was found to be $4.8 \%$ whereas the percentage of those claiming very weak vocabulary proficiency was found to be $6.6 \%$. On the other hand, the percentage of those claiming weak vocabulary proficiency was found to be $30.3 \%$, and the percentage of those claiming very good vocabulary proficiency was found to be $16.3 \%$ whereas those claiming good vocabulary proficiency were found to be $41.2 \%$.

For pronunciation, the percentage of those claiming very weak proficiency skill was found to be $9.4 \%$ and $26.5 \%$ of them were found to have stated weak pronunciation proficiency whereas $35.4 \%$ of them stated that they had average pronunciation proficiency. The percentage of those claiming good pronunciation was found to be $17.8 \%$ whereas the percentage of those claiming very good pronunciation was found to be $10.2 \%$.

For speaking, it was found that $12 \%$ of the participants were found to have claimed very weak speaking skill, and $34.4 \%$ of them were found to have stated weak speaking skill. $34.1 \%$ of them were found to have claimed average speaking skill and the percentage of those claiming good speaking skill was found to be $13.1 \%$ and the percentage of those claiming very good speaking skills was found to be $5.9 \%$.

For listening, it was found that $34.6 \%$ of the participants claimed that they found their listening skill at an average level. $5.9 \%$ of them claimed that they thought their listening skill was very weak whereas $20.4 \%$ of them found their listening skill weak. On the other hand, 9.2\% of them claimed that their listening skill was very good whereas the percentage of those claiming that their listening skill proficiency was $29.3 \%$.

For reading, the percentage of those claiming that their reading proficiency level was very weak was found to be $3.6 \%$ and those claiming that their reading proficiency level was weak were found to be $11.7 \%$. The percentage of those claiming that their reading proficiency level was at average was found to be $36.9 \%$. The percentage of those claiming that their reading proficiency level was good was found to be $31.6 \%$ whereas those claiming that their reading proficiency level was very good were found to be $15.5 \%$.

For writing, the percentage of those claiming that their writing proficiency level was very weak was found to be $5.6 \%$ and those claiming that their writing proficiency level was weak were found to be $23.2 \%$. The percentage of those claiming that their writing proficiency level was at average was found to be $30.3 \%$. The percentage of those claiming that their writing proficiency level was good was found to be $30.8 \%$ whereas those claiming that their writing proficiency level was very good were found to be $9.4 \%$.

When students' responses regarding the most often used classroom activities in English courses, it was found that individual work was the most commonly used activity by $40.7 \%$. then, in-class work was found to be the second common activity type by $19.8 \%$. CD listening is $12.7 \%$, group work is $8.1 \%$, other is $5.3 \%$, pair work is $6.4 \%$, the presentation is $2 \%$, video watching is $1 \%$, out of class Project is $1.5 \%$ and role plays is $1.5 \%$.

When students were asked what type of activities they thought would be the most beneficial for their language learning, it was found that pair work came the first by $43.3 \%$, then group work came by $28.5 \%$, and in-class work was the third often activity type by $11.7 \%$. Individual work was found to be $6.4 \%$, presentations were found to be $5 \%$, role plays was found to be $3.6 \%$, out of class activities was found to be $3.3 . \%$, other was $3 \%$, Cd listening was $1 \%$ and video watching was $1 \%$.

When we examined the responses regarding their preferred ways of learning a foreign language, it was found that $66.9 \%$ of the respondents were found to prefer learning English abroad in a country where English is spoken as a native language. 16.8\% of them were found to prefer learning English with the use of a translation-based method. The percentage of those preferring to learn English through homework was found to be $4.8 \%$. The percentage of those who believe that regularly attending English courses will help them learn English adequately was found to be $7.9 \%$. The percentage of those who prefer to learn English through private English teaching institutions was found to $2.8 \%$.

When the responses from the participants were analysed, it was also found that $35.4 \%$ of the tourism students wants one-year compulsory prep-education on English. 30.5\% of them prefer English language education through their university education rather. $21.4 \%$ of them want an optional preparatory class. The percentage of those who prefer Vocational English rather than General English was found to be $12 \%$. When 
participants were asked if they would attend preparatory class if there were any at their departments, 69.5 of them stated that they "yes" whereas $29.8 \%$ of them stated "No".

The data gathered from different tourism departments of universities regarding the items between 1016 were also submitted to Test of Homogeneity of Variances before submitting to One Way ANOVA Tukey test to reveal any meaningful difference among the classes. The score of the homogeneity test was found to be above 0,05 and then One way ANOVA Tukey test was conducted on the obtained data. To be able to draw conclusions, One Way ANOVA Tukey test was also conducted on the collected data regarding the items between 10 and 16 which are about the beliefs of the participants in their proficiency levels regarding grammar, listening, speaking, vocabulary, pronunciation, reading and writing. The findings suggest that there is a meaningful difference between the scores of 1st year students and $2 \mathrm{nd}(\mathrm{p}=, 038), 3 \mathrm{rd}(\mathrm{p}=, 048)$ and $4 \mathrm{th}(\mathrm{p}=, 029)$ year tourism students' scores in favour of the 1 st year students at ,05 significance level regarding their beliefs in their grammar proficiency levels in favour of 1st year students. For vocabulary, there has not been any meaningful difference among the classes. For pronunciation, the score of 1st year tourism students was found to be significantly different from that of 4 th year students at, 05 significance level $(p=, 006)$ in favour of the 1st year students again.

The further analysis also made clear that there was not any meaningful difference among the classes with regards to their beliefs in their Speaking, Listening, Reading and Writing proficiency levels. The data collected through the items between 22 and 47 were also submitted for One Way ANOVA Tukey HSD test to find out if there was any meaningful difference among the groups. The responses given to the item "The courses that I have taken in my department are enough for my career development" was found to be meaningfully different between the 1st year students and 2nd $(\mathrm{p}=, 000), 3 \mathrm{rd}(\mathrm{p}=, 000)$ and 4 th $(\mathrm{p}=, 000)$ year students in favour of the students in their 1st year at ,05 significance level. The data regarding the item "I would like to learn English very much" was found to be meaningfully different between the 3rd and 4th year students in favour of the 4th year students. The responses given to the item "The number of English classes per week is enough" were found to be different significantly between the 1st year students and $2 \mathrm{nd}(\mathrm{p}=, 004)$, 3 rd $(\mathrm{p}=, 010)$ and 4 th year $(\mathrm{p}=, 049)$ students in favour of $2 \mathrm{nd}$, 3rd and 4th year students at ,05 significance level. The responses given to the item "The level of English in our course books are too difficult" was found to be meaningfully different between the 1 st and 3rd year students $(\mathrm{p}=, 045)$ as well as 4 th and 3rd year students $(p=, 023)$ in favour of the $3 r d$ year students. The responses regarding the item "The course books used to teach English at our faculty contain too difficult grammar items" were found to be meaningfully different between the 2 nd and 4th year students $(\mathrm{p}=, 005)$ and 3rd and 4th year students $(\mathrm{p}=, 001)$ in favour of the $2 \mathrm{nd}$ and 3rd year students at, 05 significance level.

The responses given to the item "Our course books contain too many culture-specific details" were found to be meaningfully different between the 1st year students and $2 \mathrm{dn}(\mathrm{p}=, 028), 3 \mathrm{rd}(\mathrm{p}=, 046)$ and 4 th year $(\mathrm{p}=, 039)$ students in favour of $2 \mathrm{nd}, 3 \mathrm{rd}$ and 4 th year students. The responses given to the item "The listening records are too difficult in our course books" were also found to be significantly different between the 1st year students and 2nd ( $\mathrm{p}=, 009)$, 3rd year $(\mathrm{P}, 009)$ and 4th year students $(\mathrm{p}=, 031)$ in favour of the 2nd, 3rd and 4th year students at ,05 significance level. The responses regarding the item "My speaking skill is enough for my career in my field in Turkey" were also found to be meaningfully different between the 1st year students and 2nd $(\mathrm{p}=0,032), 3 \mathrm{rd}(\mathrm{p}=, 026)$ and 4 th year students $(\mathrm{p}=, 005)$ in favour of the 1 st year students.

The responses given to the item "My writing skill is enough for my career in my field in Turkey" were found to be meaningfully different between the 1st year students and $2 \mathrm{nd}(\mathrm{p}=, 002)$, 3rd year $(\mathrm{p}=, 000)$ and 4 th year $(p=, 000)$ students in favour of the 1 st year students at ,05 significance level. The responses given to the item "My listening comprehension skill is enough for my career in my field in a foreign country" were found to be meaningfully different between the 1st year students and 3rd year students $(p=, 014)$ and 4th year students $(\mathrm{p}=, 006)$ in favour of the 1st year students. The responses given to the item "My listening comprehension skill is enough for my career in my field in Turkey" were found to be meaningfully different between the 1st year students and 2nd year $(\mathrm{p}=, 008)$, 3rd year $(\mathrm{p}=, 000)$ and 4 th year $(\mathrm{p}=, 000)$ students in favour of the 1st year students.

The responses given to the item "My reading comprehension skill is enough for my career in my field in Turkey" were found to be meaningfully different between the 1st year students and 2 nd year $(\mathrm{p}=, 007)$, 3rd year $(\mathrm{p}=, 001)$ and 4 th year $(\mathrm{p}=, 001)$ students in favour of the 1 st year students at, 05 significance level. The 
responses given to the item "My reading comprehension skill is enough for my career in my field in a foreign country" were found to be meaningfully different between the 1st year students and 3rd year $(\mathrm{p}=, 038)$ and 4 th year $(\mathrm{p}=, 007)$ and between the 2 nd year and 4 year students $(\mathrm{p}=, 003)$ in favour of the 1 st year and 2 nd year students. The responses from the participants regarding the item "My speaking skill is enough for my career in my field in a foreign country" were found to be meaningfully different between the 1 st year students and 3rd year students $(\mathrm{p}=, 048)$ and 4 th year students $(\mathrm{p}=, 019)$ at, 05 significance level in favour of the 1st year students. Finally, the responses collected through the item "My writing skill is enough for my career in my field in a foreign country" were found to be meaningfully different between the 1st year students and 3rd year students $(\mathrm{p}=, 009)$ in favour of the 1 st year students, between the 1st year students and 4th year students $(\mathrm{p}=, 003)$ in favour of the 1st year students, between the 2 nd year students and 3rd year students $(\mathrm{p}=, 043)$ in favour of the 2nd year students and between the 2nd year students and 4th year students ( $\mathrm{p}=, 002)$ in favour of the 2 nd year students at, 05 significance level.

\section{DISCUSSION AND CONCLUSION}

Higher education first-year tourism students in Turkey identified the highest need for grammar at the very beginning of their education life at university compared to the $2^{\text {nd }}, 3^{\text {rd }}$ and $4^{\text {th }}$-year students. Similarly, the need for pronunciation was found to be the highest need for the first year students compared to the $4^{\text {th }}$ students whereas there has not been any significant difference from the $2^{\text {nd }}$ and $3^{\text {rd }}$ year students. However, the needs of higher education tourism students including $1^{\text {st }}, 2^{\text {nd }}, 3^{\text {rd }}$ and $4^{\text {th }}$ year, do not differ from one another in vocabulary, speaking, listening, reading and writing. That might be used to conclude that it takes time for tourism students to raise appropriate consciousness regarding their true need of English language. Therefore, students need to be made aware of their real needs in academic life and in their tourism career following their graduation during their university education.

The first year students consider that the English courses they take in their departments are enough to help them in their career development in tourism, but this is not the same for the $2^{\text {nd }}, 3^{\text {rd }}$ and $4^{\text {th }}$ year students. They think that the English they take in their department is not enough for a good career development in tourism in the future. That may be because of that as they come to the phase of graduation, they start to think about their life after graduation more than that of the first year students. Another finding of the research is that last year students have more motivation to learn English compared to the other classes. That may also be because they are about to start a career in their fields and they are about to face the harsh reality of the life following their graduation. Another interesting finding of the study is that the $2^{\text {nd }}, 3^{\text {rd }}$ and $4^{\text {th }}$ year students consider that the number of English class per week is enough more than that of the $1^{\text {st }}$ year students. This is an interesting finding because they seem to be happy with the amount of English in a week. That finding can be used to conclude that they are concerned about the quality of the education given rather than the amount of the English classes per week. The content of the teaching could be revised and improved to make it more fruitful in terms of achieving learning goals.

The third-year students find the difficulty level of their English course books more difficult compared to the $1^{\text {st }}$ and $4^{\text {th }}$-year students. Interestingly the $4^{\text {th }}$ year students think so less than they do. Similarly to that, the $2^{\text {nd }}$ and $3^{\text {rd }}$ year students consider that their course books contain too difficult grammar items opposed to the $4^{\text {th }}$ year students. That finding can also be used to draw a conclusion that last year students are more realistic about their language needs. The $1^{\text {st }}, 2^{\text {nd }}$ and $3^{\text {rd }}$ year students need to be made clear about their academic and career needs after graduation. Another interesting finding of the study is that the $2^{\text {nd }}, 3^{\text {rd }}$ and $4^{\text {th }}$ year students consider that their course books contain too many culture-specific details but the first year students do so less. Similarly, they also find the listening records too difficult opposed to the $1^{\text {st }}$ year students. Again, the first year students consider that their listening, reading speaking and writing skills are enough for their future career, but the other classes do not think so. That may be used to conclude that as tourism students come to the phase of graduation, they start to think more realistically about their language needs in their academic and tourism career, but it is already too late to make up for their losses regarding English proficiency.

The most common issues that can be drawn from the participants of this study are: a- the present status of English language education in tourism-related departments is not as good as expected, b- the general English textbooks do not satisfy the needs of tourism students and the course books should be changed with the ones which can meet their vocational needs following their graduation c- students are not adequately informed about their language needs in their career and therefore, more training and consciousness-raising should be done to 
help them become aware of their real needs regarding English d- English language classes should be reevaluated with regards to content and teaching methods for more fruitful learning because if learners learn better and easier when the course content and teaching methods speak to their needs as suggested by English for Specific Purpose e- listening and speaking skills should have more importance in English courses as these skills are most dominantly used in tourism sector as both students and literature claim f-course contents should be re-designed under the principles of English for Specific Purposes, which most basically give importance to the planning of English instruction considering the needs of learners. The findings of this study also contribute to new English teaching curriculum designs, textbook developments to facilitate English teaching and learning at Tourism departments at higher education institutions in Turkey. There is a need to make it clear that English for Tourism students and general English are different from one another and instructional design of English courses at tourism faculties should be redesigned in line with this difference.

\section{REFERENCES}

Afzali, K. and Rezapoorian, D. (2014). Pragmatic aspects of English for tourism course books and ESL learners pragmatic needs: A Speech act theory perspective. Elsevier 98:52-59.

Berwick, R. (1989). Needs assessment in language programming: from theory to practice. In R. K. Johnson (Ed.), The second language curriculum. (pp. 48-62). Cambridge: Cambridge University Press.

Boonyawattana, P. (1999). Needs analysis of English in the tourism business. Chiang Mai. Chiang Mai: Chiang Mai University.

Brindley, G. P. (1989). Needs assessment in language program design. In R. K. Johnson (Ed), The second language curriculum. (pp.63-78). Cambridge: Cambridge University Press.

Demirkol, Ş. and Pelit, E. (2002). Türkiye'de turizm eğitimi sistemi ve Avrupa Birliği sürecinde olası gelişmeler. Ticaret ve Turizm Fakültesi Dergisi, 2(5), 125-145.

Dudley-Evans, A. and St John, M. J. (1998). Developments in English for specific purposes: a multidisciplinary approach. Cambridge: Cambridge University Press.

Ekici, N. (2003). A needs assessment study on English language needs of the Tour Guidance students of Faculty of Applied Sciences at Baskent University. Master's Thesis, Baskent University.

Gatehouse, K. (2001). Key issues in English for Specific purposes (ESP) curriculum development. Internet TESL Journal, Vol VII, No. 10. Retrieved January 2, 2016, from http://iteslj.org/Articles/GatehouseESP.html

Hutchinson, T. and Waters, A. (1987). English for specific purposes. Cambridge: Cambridge University Press.

Keyoonwong, S. (1998). A survey of needs and wants of English in tourism career in Chiang Mai. Chiang Mai: Chiang Mai University

Kınsız, M. (2005). Mesleki yabancı dil eğitiminin sürdürülebilir gelişmeye katkıları. Selçuk Üniversitesi Sosyal Bilimler Enstitüsü Dergisi, 1(13), 259-270.

Nunan, D. (1988). The learner-centred curriculum. Cambridge: Cambridge University Press.

Richterich, R., and Chancerel, J. L. (1980). Identifying the needs of adults learning a foreign language. Oxford: Pergamon Press.

Robinson, P. (1991). ESP Today: A Practitioner's Guide. Great Britain: Prentice Hall International English Language Teaching.

Xhaferi, B. (2010). Teaching and Learning ESP Vocabulary. Biblid, 229-255.

Vellas, F. and Becherel, L. (1995). International Tourism, MacMillan Business, London.

West, R. (1994). Needs analysis in language teaching. Language Teaching, 27, 1-9.

http://dx.doi.org/10.1017/S0261444800007527 